\title{
Kötőelemek gyakorisága a magyar-angol európai parlamenti tolmácsolásban
}

Bár az Európai Parlamentben (EP) a retúr- és relétolmácsolás kis nyelvek esetében a szinkrontolmácsolási szolgáltatás fontos részét képezi, a tolmácsolás ezen formáit eddig kevéssé kutatták. A jelen tanulmány a relé- és a retúrtolmácsolást vizsgálja a kötőelemek használatán keresztül magyar-angol európai parlamenti tolmácsolásban. A jelen vizsgálat eredményei szerint ezen kötőelemek gyakoribbak a tolmácsolt, mint az eredeti diskurzusban, valamint a leggyakoribbak a relétolmácsolásban.

Kulcsszavak: korpuszalapú tolmácsoláskutatás, kötőelemek, diskurzusjelölők, relétolmácsolás, retúrtolmácsolás, európai parlamenti tolmácsolás

\section{Bevezetés}

Az EU jelenleg 24 hivatalos nyelvén 552 nyelvkombinációban fordít és tolmácsol. Ez a többnyelvűség hatalmas feladatot ró az EU működését és kommunikációját támogató nyelvi szolgáltatókra, ugyanakkor gazdag anyagot is kínál a korpuszalapú tolmácsoláskutatás viszonylag új területének (Bendazzoli, 2018) kutatásaihoz is. Az Európai Parlament (EP) üléseinek szinkrontolmácsolási anyaga mára már számos korpusz és kutatás alapját képezte (lásd Bernardini et al., 2016 az EPTIC-hez; Defrancq et al., 2015 az EPICG-hez), ahogy a jelen tanulmányét is. A jelen tanulmány magyar-angol EP-i felszólalások korpuszában (lásd Götz, 2017) vizsgálja a kötőelemek használatát. A jelen kutatás továbbá kitér az EP-i tolmácsolás egy lényeges, azonban többnyire elhanyagolt aspektusára: a relé- (közvetítő nyelvet alkalmazó, például magyar $\rightarrow$ német $\rightarrow$ angol) és a retúr- (nem az anyanyelvre [L1G, hanem idegen [L2, L3] nyelvre történő) tolmácsolásra.

A nyelvpár-kombinációk magas száma miatt már évtizedek óta lehetetlen az Európai Parlamentben minden nyelvpár között közvetlen (és/vagy anyanyelvi) tolmácsolást nyújtani (lásd Mikkelson, 1999). Különösen a kis nyelvek esetében elképzelhetetlen az európai parlamenti szinkrontolmácsolás a relé- vagy retúrtolmácsolás használata nélkül (lásd Bartłomiejczyk, 2016 a lengyel helyzethez). Annak ellenére, hogy a retúr- és relétolmácsolás használata bevett gyakorlat Európa számos kisebb nyelvpiacán, így például Közép-Kelet-Európában is (de la Iglesia \& Opdenhoff, 2014; Gentile \& Albl-Mikasa, 2017), valamint számos nemzetközi szervezetnél, ahogy például az ENSZ-nél (lásd Song \& Cheung, 2019) és az EU intézményeiben is, a témát viszonylag kevéssé kutatják. Ennek egyik oka a nem anyanyelvi tolmácsolást övező tabu, amely napjainkig hátráltatja e széles körben elterjedt tolmácsolási mód kutatását (Whyatt, 2020). 
A jelen tanulmány - Defrancq et al. (2015) vizsgálatát replikálva - ellentétes és következtető kötőelemek gyakoriságát, valamint nyelvi motiváltságát vizsgálja magyar európai parlamenti felszólalások angol szinkrontolmácsolásában, összehasonlítva az ezen kötőelemek használatában jelentkező különbségeket az anyanyelvi, retúr- és relétolmácsolásban.

\section{Kötőelemek a tolmácsolásban}

Ugyan a tágan értelmezve pragmatikai funkciót betöltő elemeket már régóta vizsgálják a tolmácsoláskutatásban (lásd Hale, 1999), rendszerezett kutatásuk csak megfelelő méretü, elektronikus tolmácsolási korpuszok megjelenésével vált lehetővé. Ez annál is fontosabb, mivel, ahogyan Hale (1999, p. 57) megjegyzi: ,a legtöbb [nyelvi] probléma, amellyel a tolmácsok megküzdenek [...] nem a terminológiai, hanem a diskurzus pragmatikai aspektusából ered”. Bizonyos tolmácsolási helyzetekben (például bírósági tolmácsolás) a tolmácsok nagy hatással vannak a tolmácsolt beszélők megítélésére pusztán az általuk megválasztott diskurzusjelölők, kötőelemek és egyéb pragmatikai jelölők révén (Hale, 2004). Mivel a tolmácsolt beszéd a hallgatóság számára rendszerint a tolmácsolt beszélőhöz, nem pedig a tolmácshoz kötődik (Blakemore \& Gallai, 2014), a stigmatizált nyelvi elemek is a beszélöre, nem pedig a tolmácsra reflektálnak, így az elöbbi megítélésre hatnak károsan.

A tolmácsok megítélését ezzel szemben beszédprodukciójuk (disz)fluenciája határozza meg alapvetően. A tolmácsolás minőségét kutató vizsgálatok rendre a fluenciát emelik ki a minőséget befolyásoló legfontosabb tényezőként (Zwischenberger, 2010). A percepciós vizsgálatok tanúsága szerint a tolmácsolt beszéd fluenciája fontosabb szempont a tolmácsolás pontosságánál is, mivel az utóbbi szempontot a befogadónak nehezebb megítélnie (Rennert, 2010). Mivel a kötőelemek alapvető szerepet játszanak a szövegkohézió megteremtésében, a tolmácsolt beszéd fluenciájának biztosításában is kiemelt a jelentôségük.

A kötőelemek ezen meghatározó szerepét az empirikus kutatások eredményei is alátámasztani látszanak. A korpuszalapú kutatások fényében a kötőelemek gyakorisága nemcsak az eredeti felszólalásokban mért gyakorisághoz képest növekszik a franciáról angolra és hollandra tolmácsolt szövegekben (Defrancq et al., 2015), hanem meghaladhatja az összehasonlítható célnyelvi szövegek gyakorisági szintjét is egyes elemek tekintetében (Defrancq, 2018; Pollkläsener, 2021). Ezzel a korpuszalapú tolmácsoláskutatásban sikerült megcáfolni azt a feltételezést, miszerint a pragmatikai funkciójú elemek gyakorisága csökken a tolmácsolt diskurzusban a nagy fokú kognitív terhelés következtében (Defrancq et al., 2015).

A megfigyelések szerint a tolmácsolás a kötőelemek szempontjából drasztikusan átalakítja az eredeti szöveg szerkezetét, amiért a hozzáadott elemek nagy száma a felelős (Defrancq et al., 2015, p. 198). A kötőelemek gyakorisága emellett szignifikánsan korrelál a beszédtempóval, és ugyan a férfiak az eddigi kutatások szerint marginálisan több kötőelemet használnak, a tolmács neme nem határozza meg a kötőelemek gyakoriságát szignifikánsan (Magnifico \& Defrancq, 2020). 


\section{Módszerek és korpusz}

\section{Kutatási célok és hipotézisek}

A jelen tanulmány a kötőelemek gyakoriságát, valamint a forrásnyelvi megfelelő nélkül hozzáadott kötőelemek arányát vizsgálja magyar-angol tolmácsolt szövegekben. A korábbi kutatások eredményei alapján a kötőelemek várhatóan gyakoribbak a tolmácsolt diskurzusban (Defrancq et al., 2015; Götz, 2019, 2020). A tanulmány a következö hipotéziseket vizsgálja:

- A kötőelemek gyakoribbak a magyarról angol tolmácsolt diskurzusban, mint a magyar forrásnyelvi szövegekben.

- A kötőelemek gyakoribbak a magyarról angol tolmácsolt diskurzusban, mint az eredeti angol diskurzusban.

- A relétolmácsolásban több forrásnyelvi megfelelő nélkül hozzáadott kötőelem található, mint a közvetlen anyanyelvi és retúr tolmácsolásban.

\section{Korpusz}

A tanulmány a MEPIK angol és magyar komponensére épül, eredeti angol és magyar, valamint magyar-angol tolmácsolt parlamenti beszédeket tartalmaz. A magyar-angol alkorpuszban háromféle tolmácsolás figyelhető meg: anyanyelvi, retúr- (magyar anyanyelvű tolmácsok angolra tolmácsolnak), valamint relétolmácsolás. A korpusz méretét az 1. táblázat mutatja.

\section{1. táblázat}

A MEPIK felépitése

\begin{tabular}{|l|c|c|}
\hline \multicolumn{1}{|c|}{ Alkorpusz } & Szószám & Beszédek \\
\hline Angol eredeti & 32656 & 106 \\
\hline Magyar forrásnyelvi & 33031 & 134 \\
\hline Angol tolmácsolt & - & - \\
\hline Angol anyanyelvi & 10220 & 28 \\
\hline Retúr & 12047 & 46 \\
\hline Relé & 15089 & 60 \\
\hline Német & 10981 & 45 \\
\hline Francia & 3166 & 13 \\
\hline Olasz & 942 & 2 \\
\hline Összesen & 37356 & 134 \\
\hline
\end{tabular}

A MEPIK-ben a legtöbb angol relétolmácsolás a német nyelvet használja közvetítő nyelvként.

\section{Módszerek}

A tanulmány a következő angol kötőelemek gyakoriságát vizsgálja: as a result, but, however, nevertheless, now, so, that is why, therefore, though, thus, well és yet, valamint ezek magyar megfelelöit (de, hanem, azonban, ezért, tehát, ugyanakkor, bár, igy, mégis, hát, viszont). 
A gyakoriságot a tanulmány abszolút és normalizált (per 1000 szó) gyakoriság formájában méri. A tolmácsolt diskurzusban megjelenő kötőelemek nyelvi motiváltságát a forrás- és célnyelvi szövegekből a Sketch Engine segítségével összeállított párhuzamos korpusz kézi elemzésével végeztem. E során a tolmácsolt angol korpuszból kivontam a vizsgált elemeket tartalmazó párhuzamos konkordanciasorokat, és azonosítottam a forrásnyelvi megfelelőt tartalmazó és azt nem tartalmazó konkordanciasorokat. A statisztikai szignifikanciát t-próba és ANOVA teszteli.

\section{Eredmények}

\section{Gyakoriság}

A 2. táblázat a kötőelemek gyakoriságát mutatja a korpuszban. A szignifikáns különbségeket * jelöli a táblázatban.

\section{2. táblázat}

A kötőelemek gyakorisága

\begin{tabular}{|l|c|c|}
\hline \multicolumn{1}{|c|}{ Korpusz } & Abszolút gyakoriság & Normalizált gyakoriság \\
\hline Tolmácsolt angol korpusz & 452 & $12,1^{*}$ \\
\hline Eredeti angol korpusz & 320 & $9,80^{*}$ \\
\hline Eredeti magyar korpusz & 371 & 11,23 \\
\hline
\end{tabular}

A három korpusz közül a tolmácsolt angol korpuszban a legmagasabb a kötőelemek gyakorisága, ezen különbség azonban csak az eredeti angol korpuszhoz képest szignifikáns statisztikailag $(t=2,87, p=0,00)$, az eredeti magyar forrásnyelvi szövegekhez képest viszont nem $(t=-0,41, p=0,34)$.

A kötőelemek gyakorisága az angol anyanyelvi, retúr- és relétolmácsolás között jelentős különbségeket mutat, ahogy azt a 3. táblázat szemlélteti, bár a különbség egyedül a relé- és az angol anyanyelvi tolmácsolás között szignifikáns $(f=2,214$, $p=0,025)$.

\section{3. táblázat}

A kötőelemek gyakorisága a három tolmácsolási csoportban

\begin{tabular}{|l|c|c|}
\hline Magyar-angol tolmácsolt korpusz & Abszolút gyakoriság & Normalizált gyakoriság \\
\hline Angol anyanyelvi tolmácsolt szövegek & 103 & $10,08^{*}$ \\
\hline Retúrtolmácsolt szövegek & 131 & 10,87 \\
\hline Relétolmácsolt szövegek & 218 & $14,45^{*}$ \\
\hline
\end{tabular}

\section{A hozzáadott és párhuzamos kötőelemek aránya}

A 4. táblázat a hozzáadott és a párhuzamos kötőelemek gyakoriságát mutatja. A tolmácsolás valamennyi típusában a hozzáadott kötőelemek száma jelentősen meghaladja a párhuzamos, vagyis forrásnyelvi megfelelővel rendelkező kötőelemek számát $(t=$ $4,09, p<0,000)$. 
Amint azt a 3. táblázat mutatja, a kötőelemek gyakoribbak a vizsgált korpuszban a relétolmácsolásban, ami mind a hozzáadott, mind a párhuzamos elemekre igaz.

\section{4. táblázat}

A hozzáadott és párhuzamos kötőelemek gyakorisága

\begin{tabular}{|l|c|c|c|c|}
\hline \multicolumn{1}{|c|}{ A tolmácsolás típusa } & \multicolumn{2}{c|}{ Hozzáadott kötöelemek } & \multicolumn{2}{c|}{ Párhuzamos kötőelemek } \\
\hline & $\begin{array}{c}\text { Abszolút } \\
\text { gyakoriság }\end{array}$ & $\begin{array}{c}\text { Normalizált } \\
\text { gyakoriság }\end{array}$ & $\begin{array}{c}\text { Abszolút } \\
\text { gyakoriság }\end{array}$ & $\begin{array}{c}\text { Normalizált } \\
\text { gyakoriság }\end{array}$ \\
\hline Angol anyanyelvi & 67 & $6,56^{*}$ & 36 & 3,52 \\
\hline Retúr & 67 & $5,56^{*}$ & 63 & 5,23 \\
\hline Relé & 141 & $9,34^{*}$ & 78 & 5,17 \\
\hline
\end{tabular}

A hozzáadott kötőelemek gyakorisága szignifikánsan gyakoribb a párhuzamos elemekénél mindhárom magyar-angol tolmácsolási csoportban (anyanyelvi: $t=1,78$, $p=0,039$; retúr: $t=0,55, p=0,29$; relé: $t=1,863, p=0,032$ ). Ugyan a hozzáadott kötőelemek gyakoribbak a relétolmácsolásban, ez a különbség statisztikailag nem szignifikáns $(f=0,04, p=0,96)$.

\section{Az egyes kötőelemek gyakorisága}

Az 5. táblázat mutatja az egyes kötőelemek normalizált gyakoriságát. Minden csoportban a but a leggyakrabban használt kötöelem, amelyet a so és a now követ, leszámítva az utóbbi elemet, amely a retúrtolmácsolásban ritkább a therefore és a however elemnél is. Az egyes kötőelemek gyakoriságának vizsgálata kimutatja, hogy a relétolmácsolásban mért magas gyakoriság két kötőelem, a but $(t=3,12, p<0,00)$ és a so $(t=$ $-1,50, p=0,07)$ magas gyakoriságának eredménye, ugyanis a legtöbb kötőelem nem gyakoribb - vagy nem szignifikánsan gyakoribb - a relétolmácsolásban.

\section{5. táblázat}

Az egyes kötőelemek normalizált gyakorisága (/1000 szó)

\begin{tabular}{|l|c|c|c|}
\hline \multicolumn{1}{|c|}{ Kötöelemek } & Relé & Angol anyanyelvi & Retúr \\
\hline as a result & 0,13 & 0,29 & 0,17 \\
\hline but & ${ }^{*} 7,56$ & 4,01 & 4,65 \\
\hline however & 0,40 & 0,49 & 0,58 \\
\hline nevertheless & 0,00 & 0,10 & 0,00 \\
\hline now & 0,93 & $* 1,86$ & 0,50 \\
\hline so & 3,71 & 2,15 & 2,99 \\
\hline that is why & 0,20 & 0,10 & 0,08 \\
\hline therefore & 0,66 & 0,59 & $* 1,16$ \\
\hline though & 0,27 & 0,10 & 0,42 \\
\hline thus & 0,07 & 0,10 & 0,08 \\
\hline well & 0,33 & 0,29 & 0,17 \\
\hline yet & 0,20 & 0,00 & 0,08 \\
\hline
\end{tabular}


A magyar retúr- és az angol anyanyelvi tolmácsolást tekintve a now szignifikánsan gyakoribb az angol anyanyelvi tolmácsolásban $(t=2,81, p<0,00)$, míg a magyar tolmácsolásban a therefore gyakoribb $(t=-1,68, p=0,05)$.

Ezek a különbségek arra hívják fel a figyelmet, hogy a tolmácsolt diskurzusban mért kötőelem-gyakoriság az egyes kötőelemek viszonylatában változó képet mutat, valamint arra is, hogy az egyes tolmácsolási módok (relé vs. közvetlen, anyanyelvi vs. retúr) hatással lehetnek rá. A különbségekre többféle magyarázat is lehetséges.

A jelen korpuszban a magyar anyanyelvủ tolmácsok a másik két tolmácsolási csoporthoz képest gyakrabban fordítanak le kötőelemeket magyarról angolra, ami arra utalhat, hogy szorosabban ragaszkodnak a magyar forrásnyelvi szöveghez, és megőrzik annak logikai kapcsolatait - ami a but, so, however, therefore és though esetében megfigyelt magasabb gyakorisághoz vezethet. Emellett a magyar anyanyelvü tolmácsok kevésbé gyakran adnak hozzá az angolra jellemző, közvetlen magyar megfelelö nélküli elemeket a célszöveghez, mint például a well vagy a now.

\section{A hozzáadott és a párhuzamos kötőelemek gyakorisága}

A 6. táblázat a hozzáadott és a párhuzamos kötőelemek arányát, a 7. táblázat pedig a kötőelemek normalizált gyakoriságát mutatja. A retúrtolmácsolásban a legalacsonyabb a hozzáadott és legmagasabb a párhuzamos kötőelemek aránya. A relé- és az anyanyelvi tolmácsolásban a hozzáadott és párhuzamos kötőelemek aránya megközelítőleg azonos.

\section{6. táblázat}

A hozzáadott és a párhuzamos kötőelemek aránya

\begin{tabular}{|c|c|c|c|c|c|c|}
\hline \multirow{2}{*}{$\begin{array}{c}\text { Kötőele- } \\
\text { mek }\end{array}$} & \multicolumn{2}{|c|}{ Angol anyanyelvi } & \multicolumn{2}{|c|}{ Retúr } & \multicolumn{2}{|c|}{ Relé } \\
\hline & Hozzáadott & $\begin{array}{l}\text { Párhuza- } \\
\text { mos }\end{array}$ & Hozzáadott & $\begin{array}{l}\text { Párhuza- } \\
\text { mos }\end{array}$ & Hozzáadott & $\begin{array}{c}\text { Párhuza- } \\
\text { mos }\end{array}$ \\
\hline as a result & $\begin{array}{c}33,33 \% \\
\text { (1) }\end{array}$ & $\begin{array}{c}66,67 \% \\
\text { (2) }\end{array}$ & $\begin{array}{c}50 \% \\
(1)\end{array}$ & $\begin{array}{c}50 \% \\
(1)\end{array}$ & $\begin{array}{c}50 \% \\
(1)\end{array}$ & $\begin{array}{c}50 \% \\
(1)\end{array}$ \\
\hline but & $\begin{array}{l}40 \% \\
(16)\end{array}$ & $\begin{array}{l}60 \% \\
(24)\end{array}$ & $\begin{array}{c}39,29 \% \\
(22)\end{array}$ & $\begin{array}{c}60,71 \% \\
(34)\end{array}$ & $\begin{array}{c}52,17 \% \\
(60)\end{array}$ & $\begin{array}{c}47,83 \% \\
(55)\end{array}$ \\
\hline however & $\begin{array}{c}20 \% \\
(2)\end{array}$ & $\begin{array}{c}80 \% \\
(4)\end{array}$ & $\begin{array}{c}14,29 \% \\
\text { (1) }\end{array}$ & $\begin{array}{c}85,71 \% \\
\text { (6) }\end{array}$ & $\begin{array}{c}16,67 \% \\
\text { (1) }\end{array}$ & $\begin{array}{c}83,33 \% \\
(5)\end{array}$ \\
\hline nevertheless & $\begin{array}{c}100 \% \\
(1)\end{array}$ & $\begin{array}{l}0 \% \\
(0)\end{array}$ & $\begin{array}{l}0 \% \\
(0)\end{array}$ & $\begin{array}{l}0 \% \\
(0)\end{array}$ & $\begin{array}{l}0 \% \\
(0)\end{array}$ & $\begin{array}{l}0 \% \\
(0)\end{array}$ \\
\hline now & $\begin{array}{c}94,74 \% \\
(18)\end{array}$ & $\begin{array}{l}5,26 \% \\
\text { (1) }\end{array}$ & $\begin{array}{c}100 \% \\
(6)\end{array}$ & $\begin{array}{l}0 \% \\
(0)\end{array}$ & $\begin{array}{c}92,86 \% \\
(13)\end{array}$ & $\begin{array}{l}7,14 \% \\
\text { (1) }\end{array}$ \\
\hline so & $\begin{array}{c}90,48 \% \\
(19)\end{array}$ & $\begin{array}{c}9,52 \% \\
(2)\end{array}$ & $\begin{array}{c}77,14 \% \\
(27)\end{array}$ & $\begin{array}{c}22,86 \% \\
\text { (8) }\end{array}$ & $\begin{array}{c}82,76 \% \\
(48)\end{array}$ & $\begin{array}{c}17,24 \% \\
(10)\end{array}$ \\
\hline that is why & $\begin{array}{c}100 \% \\
(1)\end{array}$ & $\begin{array}{l}0 \% \\
(0)\end{array}$ & $\begin{array}{l}0 \% \\
(0)\end{array}$ & $\begin{array}{c}100 \% \\
(1)\end{array}$ & $\begin{array}{c}66,67 \% \\
(2)\end{array}$ & $\begin{array}{c}33,33 \% \\
\text { (1) }\end{array}$ \\
\hline therefore & $\begin{array}{c}66,67 \% \\
\text { (4) }\end{array}$ & $\begin{array}{c}33,33 \% \\
\text { (2) }\end{array}$ & $\begin{array}{c}35,71 \% \\
\text { (5) }\end{array}$ & $\begin{array}{c}64,29 \% \\
\text { (9) }\end{array}$ & $\begin{array}{c}80 \% \\
(8)\end{array}$ & $\begin{array}{c}20 \% \\
(2)\end{array}$ \\
\hline
\end{tabular}




\begin{tabular}{|l|c|c|c|c|c|c|}
\hline though & $\begin{array}{c}0 \% \\
(0)\end{array}$ & $\begin{array}{c}0 \% \\
(0)\end{array}$ & $\begin{array}{c}40 \% \\
(2)\end{array}$ & $\begin{array}{c}60 \% \\
(3)\end{array}$ & $\begin{array}{c}80 \% \\
(4)\end{array}$ & $\begin{array}{c}20 \% \\
(1)\end{array}$ \\
\hline thus & $0 \%$ & $100 \%$ & $100 \%$ & $0 \%$ & $100 \%$ & $0 \%$ \\
& $(0)$ & $(1)$ & $(1)$ & $(0)$ & $(1)$ & $(0)$ \\
\hline \multirow{2}{*}{ well } & $100 \%$ & $0 \%$ & $100 \%$ & $0 \%$ & $100 \%$ & $0 \%$ \\
& $(3)$ & $(0)$ & $(2)$ & $(0)$ & $(5)$ & $(0)$ \\
\hline yet & $0 \%$ & $0 \%$ & $0 \%$ & $100 \%$ & $33,33 \%$ & $66,67 \%$ \\
& $(0)$ & $(0)$ & $(0)$ & $(1)$ & $(1)$ & $(2)$ \\
\hline Összesen & $64 \%$ & $36 \%$ & $51,54 \%$ & $48,46 \%$ & $64,86 \%$ & $35,14 \%$ \\
& $(64)$ & $(36)$ & $(67)$ & $(63)$ & $(144)$ & $(78)$ \\
\hline
\end{tabular}

\section{7. táblázat}

A hozzáadott és a párhuzamos kötőelemek normalizált gyakorisága

\begin{tabular}{|l|c|c|c|c|c|c|}
\hline Kötöelemek & \multicolumn{2}{|c|}{ Angol anyanyelvi } & \multicolumn{2}{c|}{ Retúr } & \multicolumn{2}{c|}{ Relé } \\
\hline & Hozzáadott & $\begin{array}{c}\text { Párhuza- } \\
\text { mos }\end{array}$ & Hozzáadott & $\begin{array}{c}\text { Párhuza- } \\
\text { mos }\end{array}$ & Hozzáadott & $\begin{array}{c}\text { Párhuza- } \\
\text { mos }\end{array}$ \\
\hline as a result & 0,10 & 0,20 & 0,08 & 0,08 & 0,07 & 0,07 \\
\hline but & 1,66 & 2,35 & 1,83 & 2,82 & 3,91 & 3,65 \\
\hline however & 0,10 & 0,39 & 0,08 & 0,50 & 0,07 & 0,33 \\
\hline nevertheless & 0,10 & 0,00 & 0,00 & 0,00 & 0,00 & 0,00 \\
\hline now & $1,76^{*}$ & 0,10 & $0,50^{*}$ & 0,00 & $0,86^{*}$ & 0,07 \\
\hline so & $1,96^{*}$ & 0,20 & $2,24^{*}$ & 0,66 & $3,11^{*}$ & 0,66 \\
\hline that is why & 0,10 & 0,00 & 0,00 & 0,08 & 0,13 & 0,07 \\
\hline therefore & 0,39 & 0,20 & 0,42 & 0,75 & 0,53 & 0,13 \\
\hline though & 0,10 & 0,00 & 0,17 & 0,25 & 0,20 & 0,07 \\
\hline thus & 0,00 & 0,10 & 0,08 & 0,00 & 0,07 & 0,00 \\
\hline well & 0,29 & 0,00 & 0,17 & 0,00 & 0,33 & 0,00 \\
\hline yet & 0,00 & 0,00 & 0,00 & 0,08 & 0,07 & 0,13 \\
\hline Összesen & $\mathbf{6 , 2 6 *}$ & $\mathbf{3 , 5 2}$ & $\mathbf{5 , 5 6}$ & $\mathbf{5 , 2 3}$ & $\mathbf{9 , 5 4}$ & $\mathbf{5 , 1 7}$ \\
\hline
\end{tabular}

Egyik tolmácsolási csoportban sem haladja meg szignifikánsan a hozzáadott kötőelemek gyakorisága a párhuzamosokét. A but mindhárom tolmácsolási csoportban a leggyakoribb kötőelem, azonban a hozzáadott kötőelemek gyakorisága nem haladja meg szignifikánsan a párhuzamosokét. A now esetében mindhárom csoportban szignifikánsan gyakoribbak a hozzáadott kötőelemek (anyanyelvi: $t=2,11, p=0,02$; relé: $t=1,87, p=0,034$; retúr: $t=2,51, p=0,011$ ), ahogy a so esetében is (anyanyelvi: $t$ $=3,63, p<0,000$; retúr: $t=2,55, p=0,01$; relé: $t=4,56, \mathrm{p}<0,000$ ).

A gyakorisági adatok fényében elképzelhetö továbbá az is, a magyar anyanyelvü tolmácsok inkább az általánosabb funkciójú, alapszókincshez tartozó kötőelemeket használják, mint a speciálisabb jelentésủeket. Ez esetben azonban feltételezhetnénk, 
hogy a specifikusabb kötőelemek markánsan ritkábbak a retúr-, mint az anyanyelvü angol tolmácsolási csoportokban, a gyakorisági adatok azonban nem támasztják alá ezt, így valószínủleg a but magasabb gyakorisága a magyar tolmácsok körében nem a kötőelemek korlátozottabb használatára vezethető vissza.

\section{Következtetés}

A jelen tanulmány a kötőelemek gyakoriságát vizsgálta magyar-angol európai parlamenti szinkrontolmácsolásban. Az elemzések számos megállapításhoz vezettek:

- a kötőelemek gyakoribbak a tolmácsolt angolban, mint az eredeti angol EP-diskurzusban, vagy a magyar forrásbeszédekben;

- a kötőelemek leggyakoribbak a relétolmácsolásban, mind a hozzáadott, mind a párhuzamos kötőelemek normalizált gyakoriságát tekintve;

- a retúrtolmácsolásban a legmagasabb a párhuzamos kötőelemek gyakorisága.

Az eredmények alátámasztják mindhárom hipotézist. A kötőelemek egyrészt gyakoribbak a tolmácsolt, mint az eredeti angol vagy magyar forrásbeszédekben, továbbá a relétolmácsolásban a leggyakoribbak. Az elemzések ezenkívül kimutatták azt is, hogy a hozzáadott és párhuzamos kötőelemek aránya eltér a retúr-, az anyanyelvi angol és a relétolmácsolásban. Míg egyes kötőelemek tekintetében az angol anyanyelvi és a retúrtolmácsolás között nyelvspecifikus különbségek mutatkoznak, a két csoport összesített kötőelem-gyakorisága nem tér el szignifikánsan.

Bernardini et al. (2016) az olasz-angol tolmácsolásban megfigyelhetö lexikai és szintaktikai egyszerüsítést vizsgálva megállapította, hogy a tolmácsolt diskurzus egyszerre viseli a közvetített és a beszélt diskurzus nyelvi jegyeit, a kettő szélsőséges esetét képviselve. Ennek alapján feltételezhető, hogy a relétolmácsolás a tolmácsolt diskurzus szélsőséges esetét testesíti meg, amelyben a tolmácsolt diskurzus jellemző tulajdonságai felerősítve jelennek meg.

Mindazonáltal a jelen kutatás alapján általános következtetések nem vonhatók le, az eredmények ehelyett további kutatások lehetséges kérdéseit vázolják fel. Így például felmerül a kérdés, hogy a relétolmácsolás esetében általános tendencia-e a kötőelemek magasabb gyakorisága? Ezenkívül a - szintén kevéssé kutatott - retúrtolmácsolást tekintve további vizsgálatot igényel a tolmácsok anyanyelvének hatása mind a kötőelemek köre, mind azok gyakoriságának tekintetében.

\section{IRODALOM}

Bartłomiejczyk, M. (2016). Face threats in interpreting: A pragmatic study of plenary debates in the European Parliament. Wydawnictwo Uniwersytetu Śląskiego.

Bendazzoli, C. (2018). Corpus-Based Interpreting Studies: Past, Present and Future Developments of a (wired) Cottage Industry. In M. Russo, C. Bendazzoli, \& B. Defrancq (Eds.), Making Way in Corpus-Based Interpreting Studies (pp. 1-19). Springer. https://doi.org/10.1007/978-981-10-6199-8_1

Bernardini, S., Ferraresi, A. \& Miličević, M. (2016). From EPIC to EPTIC - Exploring simplification in interpreting and translation from an intermodal perspective. Target, 28(1), 61-86. https://doi. org/10.1075/target.28.1.03ber 
Blakemore, D. \& Gallai, F. (2014). Discourse markers in free indirect style and interpreting. Journal of Pragmatics, 60, 106-120. https://doi.org/10.1016/j.pragma.2013.11.003

Collard, C. \& Defrancq, B. (2020). Disfluencies in simultaneous interpreting a corpus-based study with special reference to sex. In L. Vandevoorde, J. Daems, \& B. Defrancq (Eds.), New Empirical Perspectives on Translation and Interpreting (pp. 264-300). Routledge. https://doi. org/10.4324/9780429030376

de la Iglesia, M. B., \& Opdenhoff, J.-H. (2014). Retour Interpreting Revisited: Tuning Competences in Interpreter Education. Current Trends in Translation Teaching and Learning, 10, 4-43.

Defrancq, B. (2016). Well, interpreters... a corpus-based study of a pragmatic particle used by simultaneous interpreters. In G. Corpas Pastor \& M. Seghiri (Eds.), Corpus-based Approaches to Translation and Interpreting (pp. 105-128). Peter Lang. https://doi.org/10.3726/b10354

Defrancq, B. (2018). The European Parliament as a discourse community: Its role in comparable analyses of data drawn from parallel interpreting corpora. The Interpreters' Newsletter, 23, 115-132. https://doi.org/10.13137/2421-714x/22401

Defrancq, B., Plevoets, K. \& Magnifico, C. (2015). Connective Items in Interpreting and Translation: Where Do They Come From? In J. Romero-Trillo (Ed.), Yearbook of Corpus Linguistics and Pragmatics 2015 (Vol. 3, pp. 195-222). Springer. https://doi.org/10.1007/978-3-319-17948-3 9

Gentile, P. \& Albl-Mikasa, M. (2017). 'Everybody Speaks English Nowadays'. Conference Interpreters' Perception of the Impact of English as a Lingua Franca on a Changing Profession. Cultus, 53-66.

Götz, A. (2017). Az első magyar intermodális korpusz bemutatása. Kutatási lehetőségek. Argumentum, $13,126-139$.

Götz, A. (2019). Diskurzusjelölők és kötőelemek gyakorisága írott és beszélt, mediált és nem mediált diskurzusokban. In K. Laczkó \& Sz. Tátrai (Eds.), Kontextualizáció és metapragmatikai tudatosság (pp. 291-313). ELTE Eötvös József Collegium.

Götz, A. (2020). Discourse markers and connectives in interpreted Hungarian discourse: A corpus-based investigation of discourse properties and their interdependence. Speech Science, 2020(1), 259-284. https://doi.org/10.15775/Besztud.2020.259-28

Magnifico, C. \& Defrancq, B. (2017). Hedges in conference interpreting: The role of gender. Interpreting, 19(1), 21-46. https://doi.org/10.1075/intp.19.1.02mag

Magnifico, C. \& Defrancq, B. (2020). Norms and gender in simultaneous interpreting: A study of connective markers. Translation \& Interpreting, 12(1), 1-17. https://doi.org/10.12807/ti.112201.2020.a01

Magnifico, C. \& Defrancq, B. (2020). Norms and gender in simultaneous interpreting: A study of connective markers. Translation \& Interpreting, 12(1), 1-17. https://doi.org/10.12807/ti.112201.2020.a01

Mikkelson, H. (1999). Relay Interpreting: A Solution for Languages of Limited Diffusion? The Translator, 5(2), 361-380. https://doi.org/10.1080/13556509.1999.10799051

Plevoets, K. \& Defrancq, B. (2018). The cognitive load of interpreters in the European Parliament: A corpus-based study of predictors for the disfluency uh(m). Interpreting, 20(1), 1-28. https://doi. org/10.1075/intp.00001.ple

Pollkläsener, C. (2021, September 5). A Comparison of Discourse Particles in English Original and Simultaneous Interpreted Speeches. UCCTS 2021, Bertinoro.

Rennert, S. (2010). The impact of fluency on the subjective assessment of interpreting quality. The Interpreters' Newsletter, 15, 101-115.

Song, S. \& Cheung, A. K. F. (2019). Disfluency in relay and non-relay simultaneous interpreting: An initial exploration. FORUM, 17(1), 1-19. https://doi.org/10.1075/forum.18016.che

Whyatt, B. (2020, November 12). Directionality in translation and interpreting [Online lecture]. MC2 Lab's Food for Thought Online Lecture Series. https:/www.youtube.com/watch?v=UoT86V6ipB0 (2021.10.11.) 
Zwischenberger, C. (2010). Quality criteria in simultaneous interpreting: An international vs. a national view. The Interpreters' Newsletter, 15, 127-142.

\title{
The frequency of connective items in Hungarian to English European Parliamentary interpreting
}

\begin{abstract}
Although simultaneous interpreting in the European Parliament (EP) would be impossible without retour and relay interpreting, especially in the case of small languages, these modes of interpreting have received little attention so far. This paper examines relay and retour interpreting through the use of connective items in Hungarian-to-English European Parliamentary interpreting. The results show that connective items are more frequent in interpreted than in original discourse, and most frequent in relay interpreting.
\end{abstract}

Keywords: corpus-based interpreting, connective items, discourse markers, relay interpreting, retour interpreting, EP interpreting 